\title{
RISK OF ASTHMA SYMPTOMS AMONG WORKERS IN HEALTH CARE SETTINGS
}

\author{
MUSTAFA AL-ZOUGHOOL \& RANA AL-MISTNEER \\ Department of Community and Environmental Health, King Saud Bin Abdulaziz University for Health Sciences, \\ Riyadh, Saudi Arabia.
}

\begin{abstract}
Prevalence of asthma is quite high in health care settings due to exposure to a wide variety of substances, including cleaning products, latex, medicines, ammonia and solvents. In this cross-sectional study, participants completed a validated questionnaire about their occupation, asthma diagnosis, variability of asthma symptoms at and away from work, and exposure to individual substances in the workplace. Work-related asthma symptoms (WRAS) were defined based on a set of criteria. Principal component analysis (PCA) was conducted to classify different substances into exposure patterns. Multivariable logistic regression analysis was used to evaluate the association between self-reported exposures to substances and asthma outcomes among health care workers. PCA revealed two factors: factor 1 (metal dust, metal fumes, solvents, cleaning agents, ammonia, glues) and factor 2 (disinfectants, latex, medicines). Exposure to factor 1 agents was associated with increased risk of WRAS (crude odds ratio (OR) $5.52,95 \%$ confidence intervals (CI) 2.72-11.19), while exposure to factor 2 agents was associated with non-significant lower risk of WRAS (crude OR $0.58,95 \%$ CI $0.3-1.14$ ). Adjusting by confounders such as parent's allergy and history of asthma, or smoking, did not appreciably change the ORs. Some agents were associated with increased risk of WRAS, while the lack of association with the exposure to other set of chemicals may be attributed to a number of factors, including healthy worker effect.
\end{abstract}

Keywords: chemical exposures, disinfectants, health care, solvents, work-related asthma symptoms.

\section{INTRODUCTION}

Asthma is a prevalent disease that affects people of all ages and across many countries $[1,2]$. Estimates of the disease prevalence in Western countries show a range of 5-10\% of the general population [3]. Although genetic background is a factor in the development of asthma, environmental and occupational factors contribute to a substantial proportion of the disease. Reviews from a number of countries worldwide suggest that $10-15 \%$ of adult asthma can be attributed to occupational exposures [4, 5]. However, depending on the industry, work-related factors can be responsible for up to one-third of adult asthma cases [6]. Common industries and occupations associated with asthma in both industrialized and developing countries include manufacturing, farming, baking, painting, health care, agriculture and mining [7]. Estimates from the United States have shown that mining (17\%), health-related industries $(12.5 \%)$ and teaching (13\%) had been associated with highest prevalence of asthma [8].

Health care workers (HCWs) are exposed to a wide range of substances, some of which have already been identified as causative agents for asthma [9]. Examples of substances used in health care settings include medicines, solvents and latex. Non-medical staff such as maintenance workers, administrative assistants and cleaners can also be exposed to metal dust and fumes, detergents, glues, bleach, ammonia and other materials. Several previous studies showed that either HCWs are at increased risk of occupational asthma or asthma is more common among HCWs [10-14].

In the developing countries, surveillance systems of occupational exposures either do not exist or are poorly implemented, resulting in underestimation of the number of occupationrelated diseases and illnesses [15]. In particular, very few studies investigated the prevalence of occupational asthma among HCWs in developing countries [7]. 
The current study estimated the prevalence of asthma-related symptoms among workers in the hospital environment and examined the association of these effects with exposure to several substances. Unlike previous studies, the current study surveyed non-medical staff who may be exposed to distinct group of substances. Diagnosis of occupational asthma is quite difficult in health care settings; therefore, we relied on an outcome that represents an intermediary step in the pathway of occupational asthma development. This outcome is referred to work-related asthma symptoms (WRAS).

\section{MATERIALS AND METHODS}

\subsection{Study population}

The study was carried out in a main hospital in Riyadh city; the hospital is located in a medical campus which contains other auxiliary facilities such as auto and elevator repair workshops. Population surveyed in the current study included medical and non-medical staff. The sample of medical staff included nurses, physician/doctor, physical therapist, respiratory therapist and pharmacists. Non-medical staff included drivers, maintenance workers and administrative assistants. The study was approved by the King Abdullah International Medical Research Center. Each participant provided informed consent before they took part in the study.

\subsection{Data collection}

Interviews were conducted by a trained research assistant using the itemized questionnaire that was based on a previously validated instrument [16]. Questions included socio-economic status indicators (income, home ownership, level of education), profession and smoking. Other questions related to environmental exposures include indoor house environment and house proximity to major highways. Information on occupational exposures included occupation type and duration, nature of job duties, and exposure frequency to substances. The risk of WRAS was determined based on responses to a set of questions reported in an earlier study [16]. Briefly, the questions focus on specific symptoms and their temporality in relation to presence in or being away from the workplace.

\subsection{Self-reported exposures}

A detailed history of the job held longest by the study participant was collected using the questionnaire. Each participant was asked about frequency of exposure - in their longest held job - to a list of chemicals including medicines, latex, solvents, metal and dust fumes.

\subsection{Statistical analysis}

The exploratory principal component analysis (PCA) was implemented to identify patterns of exposures substances in the workplace. The number of factors retained was based on the Kaiser criterion (eigenvalues $>1$ ). Then patterns of exposures were defined based on individual factor loadings of the different workplace substances. A summary variable of presence or absence $(0,1)$ of exposure to a given group of chemicals was generated by summing scores of exposures to each of the individual substances in that group. Weighted prevalence analyses of WRAS were performed. Odds ratio (OR) and $95 \%$ confidence intervals (CI) of WRAS 
were calculated in relation to the exposure patterns resulting from PCA. The outcome variable WRAS was compared to the common baseline/reference category (none) using a logistic regression model, adjusted for age, sex, BMI, smoking status, and host-related factors such as mother and father's allergies and sensitivity, and nursery school attendance. All analyses were conducted using SAS Statistical Software Package v 9.4.

\section{RESULTS}

Table 1 shows major demographic characteristics of the study subject.

Table 2 shows the percentage of subjects within each category of exposures to the different substances. We ordered exposure frequencies from the highest to the lowest of everyday exposures. Exposure to disinfectants was the most prevalent followed by exposure to latex gloves, then floor cleaning chemicals, antibiotics and anaesthetics.

Table 1: Demographic characteristics of the interviewed subjects $(n=285)$.

\begin{tabular}{lc}
\hline Mean age (SD) & $30.9(6.1)$ \\
\hline$\%$ males & 25 \\
Nationality & $76 \%$ \\
Non-Saudi & \\
Job title & $54 \%$ \\
Nurse & $9 \%$ \\
Physician/doctor & $7 \%$ \\
Respiratory therapist & $9 \%$ \\
Pharmacist & $21 \%$ \\
Non-medical (cleaner, drivers, painters, auto & \\
mechanics, maintenance workers) & $23.9(5)$ \\
Mean BMI (SD) & $16.2 \%$ \\
Work-related wheezing & $5.4 \%$ \\
Work-related shortness of breath & $5.7 \%$ \\
Work-relate asthma symptoms & $5.4 \%$ \\
Doctor diagnosed asthma &
\end{tabular}

Table 2: Percentage of individuals in each category of exposure frequency ranked from highest to lowest exposure frequency.

\begin{tabular}{|c|c|c|c|c|}
\hline \multirow{2}{*}{ Product } & \multicolumn{4}{|c|}{$\%$ with exposure frequency } \\
\hline & Every day & $\begin{array}{l}\text { At least } \\
\text { once a week }\end{array}$ & $\begin{array}{l}\text { At least } \\
\text { once/month }\end{array}$ & Never \\
\hline Disinfectants, sterilizers or alcohol & 90.91 & 5.19 & 1.3 & 2.6 \\
\hline Latex or latex gloves & 70.93 & 3.08 & 3.96 & 22.03 \\
\hline $\begin{array}{l}\text { Floor cleaning agents, bleach, vacuum } \\
\text { dust, alkali or formaldehyde }\end{array}$ & 58.26 & 25.65 & 6.52 & 9.57 \\
\hline $\begin{array}{l}\text { Anaesthetics, antibiotics, bronchodilators, } \\
\text { iodine or nebulized drugs }\end{array}$ & 47.6 & 9.17 & 23.58 & 19.65 \\
\hline Meta dust, insulation dust or printers dust & 33.92 & 12.78 & 16.3 & 37 \\
\hline
\end{tabular}


Table 2: Continued

\begin{tabular}{lcccc}
\hline & \multicolumn{4}{c}{$\%$ with exposure frequency } \\
\cline { 2 - 5 } Product & Every day & $\begin{array}{l}\text { At least } \\
\text { once a week }\end{array}$ & $\begin{array}{l}\text { At least } \\
\text { once/month }\end{array}$ & Never \\
\hline Metal fumes, diesel exhaust emission & 26.63 & 23.62 & 10.05 & 39.7 \\
Adhesives or glues & 7.34 & 7.91 & 38.98 & 45.76 \\
$\begin{array}{l}\text { Ammonia, paints, ethylene oxides, } \\
\text { acetaldehyde }\end{array}$ & 4.8 & 4.8 & 29.26 & 61.14 \\
$\begin{array}{l}\text { Solvents (e.g. toluene, xylene, benzene, } \\
\text { paint thinners, tonners etc.). }\end{array}$ & 3.67 & 5.05 & 28.9 & 62.39 \\
\hline
\end{tabular}

Table 3: Eigenvalues of factor analysis.

\begin{tabular}{lcccc}
\hline Factor & Eigenvalue & Difference & Proportion & Cumulative \\
\hline------------- & $\mathbf{0 . 3 7 2 3}$ & $\mathbf{0 . 3 7 2 3}$ \\
Factor 1 & $\mathbf{3 . 3 5 0 5 4}$ & $\mathbf{1 . 5 1 2 6 1}$ & $\mathbf{0 . 2 0 4 2}$ & $\mathbf{0 . 5 7 6 5}$ \\
Factor 2 & $\mathbf{1 . 8 3 7 9 3}$ & $\mathbf{0 . 8 7 5 9 4}$ & 0.1069 & 0.6834 \\
Factor 3 & 0.96199 & 0.22254 & 0.0822 & 0.7655 \\
Factor 4 & 0.73945 & 0.15775 & 0.0646 & 0.8302 \\
Factor 5 & 0.58170 & 0.04854 & 0.0592 & 0.8894 \\
Factor 6 & 0.53316 & 0.10836 & 0.0472 & 0.9366 \\
Factor 7 & 0.42480 & 0.03075 & 0.0438 & 0.9804 \\
Factor 8 & 0.39405 & 0.21768 & 0.0196 & 1.0000 \\
Factor 9 & 0.17637 & $\cdot$ &
\end{tabular}

We conducted PCA to classify exposures into the different patterns or groups. Table 3 shows Eigenvalues for the factors in this survey of exposures. As used by the literature, only Eigenvalues of more than 1 are retained for further analyses. As a result, the first two factors were retained.

Table 4 shows the factor loadings for the different types of exposures in the workplace in the two factors. Exposures to the following types of chemicals: metal dust, or insulation dust or printers dust, metal fumes, or diesel exhaust emission, floor cleaning agents or bleach or vacuum dust, alkali, or formaldehyde, ammonia, or paints, or ethylene oxides, or acetaldehyde, solvents (e.g. toluene, xylene, benzene, paint thinners and tonners), adhesives or glues, were all loaded together in factor 1 . However, factor 2 included exposures to the following chemicals: disinfectants or sterilizers, or alcohol, latex or latex gloves, anaesthetics or antibiotics or bronchodilators, iodine, or nebulized drugs.

We then conducted logistic regression to determine the risk of WRAS in relation to these two exposure factors. Subjects with everyday exposures to the individual chemicals within factors 1 and 2, respectively, were placed in one group. Table 5 shows the crude and adjusted OR and their $95 \%$ CIs. The results show significant increased risk of WRAS with exposure to agents in factor 1 (OR 5.52, 95\% CI 2.24-9.73). However, exposure to agents in factor 2 was associated with lower insignificant risk (OR 0.58, 95\% CI 0.30-1.14). Adjusting for confounding variables (mother allergy, mother asthma, father allergy, nursery school attendance 
Table 4: Factor loadings for the different exposure materials in the two factors.

\begin{tabular}{|c|c|c|c|}
\hline Substance & Factor 1 & Factor 2 & Uniqueness \\
\hline Insulation dust or printers dust & 0.6614 & -0.2964 & 0.4747 \\
\hline Disinfectants, sterilizers, or alcohol & 0.402 & 0.6244 & 0.4486 \\
\hline Latex or latex gloves & 0.449 & 0.7053 & 0.3009 \\
\hline Metal fumes, metal dust & 0.7516 & -0.2644 & 0.3652 \\
\hline $\begin{array}{l}\text { Floor cleaning agents or bleach or vacuum dust, } \\
\text { alkali, or formaldehyde }\end{array}$ & 0.6784 & 0.3873 & 0.3898 \\
\hline $\begin{array}{l}\text { Anaesthetics, antibiotics, bronchodilators, iodine, } \\
\text { or nebulized drugs }\end{array}$ & 0.2015 & 0.6513 & 0.5353 \\
\hline $\begin{array}{l}\text { Ammonia, paints, ethylene oxides, } \\
\text { or acetaldehyde }\end{array}$ & 0.6579 & -0.2145 & 0.5212 \\
\hline $\begin{array}{l}\text { Solvents (e.g. toluene, xylene, benzene, paint } \\
\text { thinners and tonners). }\end{array}$ & 0.7363 & -0.286 & 0.3761 \\
\hline Adhesives or glues & 0.7137 & -0.3016 & 0.3997 \\
\hline
\end{tabular}

Table 5: Results of logistic regression of the risk of WRAS and exposure to chemicals in the workplace adjusted for other risk factors.

\begin{tabular}{lcccccc}
\hline $\begin{array}{l}\text { Exposure } \\
\text { to factors }\end{array}$ & \multicolumn{2}{l}{$\begin{array}{l}\text { Work-related } \\
\text { asthma symptoms }\end{array}$} & \multicolumn{5}{c}{$\begin{array}{l}\text { ORs and the 95\% } \\
\text { confidence intervals }\end{array}$} \\
\hline & No & Yes & Crude OR & 95\% CI & $\begin{array}{l}\text { Adjusted } \\
\text { OR** }\end{array}$ & 95\% CI \\
Factor 1* & & & & & & \\
No & 92 & 8 & 1 & & 1.0 & - \\
Yes & 31 & 71 & 5.52 & $2.24-9.73$ & 6.35 & $2.47-14.37$ \\
Factor 2* & & & & & 1.0 & - \\
No & 77 & 23 & 1 & & 0.56 & $0.23-1.33$ \\
Yes & 85 & 15 & 0.58 & $0.30-1.14$ & 0.53 \\
\hline
\end{tabular}

*Factor 1: metal dust, metal fumes, cleaning agents, ammonia, glues; factor 2: disinfectants, latex and medicines.

**Adjusted for gender, mother allergy, mother asthma, father allergy, nursery school attendance and smoking status.

and smoking status) somewhat strengthened the association of exposure to agents in factor 1 (adjusted OR 6.35, 95\% CI 2.47-14.37). Adjusting by the same confounders did not change the OR of WRAS for exposures to agents in factor 2 (OR 0.56, 95\% CI 0.23-1.33).

\section{DISCUSSION}

The current results showed high frequency exposures to substances normally encountered in the hospital environment. For example, more than $90 \%$ of the interviewed subjects are exposed to disinfectants, sterilizers, or alcohol every day, and about $71 \%$ are exposed to floor cleaning agents, bleach vacuum dust, alkali, or formaldehyde. Exposure to agents such as metal dust, metal fumes, cleaning agents, ammonia, solvents and glues was associated 
with significant increased risk of WRAS (adjusted OR 6.35, 95\% CI, 2.47-14.37). Exposure to the other group of substances (disinfectants, latex, medicines) was associated with nonsignificant lower risk (adjusted OR 0.56, 95\% CI, 0.23-1.33).

Exposure to metal fumes and metal dust during welding is associated with respiratory health effects that include chronic bronchitis, lung function abnormalities and occupational asthma [17-19]. Jaakkola et al. (2003) reported that the metal work was the second strongest determinant of asthma among male-dominated occupations [20]. The composition and levels of metals in metal fumes vary depending on the type of metal used and welding method [21]. Those fumes may also contain particulate matter of aerodynamic diameter of $<2.5 \mu \mathrm{m}$ (PM2.5) and zinc oxide particles with an aerodynamic diameter of $<0.1 \mu \mathrm{m}$ (PM0.1) [22]. Chromium and/or nickel and other metals generated during welding of stainless steel have been documented to induce asthma in other occupations [23]. The results of a recent study by Huang et al. (2016) [24] suggested that asthma prevalence in the Chinese adults was positively associated with urinary levels of several metals including $\mathrm{Cr}, \mathrm{Cu}, \mathrm{Se}$, Mo and Cd. Metalinduced asthma is of the irritant type and is mediated by IgE immunoglobulin release [25].

Many of the cleaning substances commonly used in hospitals are highly volatile and pose respiratory health risks [26]. Examples of such substances include bleach, acetic acid and ammonia. Non-medical staff - mostly cleaners - may be exposed to high levels of detergents and other cleaning products. Bleach is widely used as disinfectant to clean medical instruments and hospital floors. Several studies reported an association between exposure to this agent and asthma or asthma symptoms [27-33]. Similarly, exposure to ammonia was linked to work-related asthma among HCWs [26, 34] and in occupational domestic cleaning [35]. Formalin is used in hospitals for a variety of purposes such as disinfection, staining and fixing of tissues. It has been linked to asthma or asthma symptoms for medical staff [34].

Nursing and other health professionals conduct tasks that involve exposure to adhesive compounds, glues and/or solvents [36]. In the same study exposure to adhesives, glues and/or solvents was associated with a two-fold increase in the odds of reported asthma, but not after adjustment for covariates. However, factor analysis in the current study revealed that solvents loaded into factor 1 agents, which also included metal dust, metal fumes, cleaning agents, ammonia and glues. These agents were probably encountered in some non-medical occupations in health care facilities. The current study was carried out in major medical complex that has its own maintenance units such as auto and elevator repair, reconstruction and refurbishing. We interviewed drivers, administrative assistants and maintenance workers (e.g. auto mechanics). They probably defined exposures to factor 1 agents. Exposure to solvents in hospitals can also occur in cleaners [37], painters and auto mechanics. Unintentional solvent exposure among medical and non-medical staff can also occur during accidents in hospitals [38].

Current results showed that exposure to substances in factor 2 (latex, disinfectants and medications) was associated with somewhat lower risk of WRAS. These exposures commonly occur among medical staff such as nurses, physicians and laboratory technicians. A recent survey of 182,825 adults in 35 states in the US Health Care Worker Survey [10] estimated higher prevalence ratios (PR) of asthma attacks among HCWs (PR = 1.23, 95\% CI 1.03-1.46). In addition, several other studies reported increased risk for both asthma and work-related asthma among HCWs [11-14]. Nevertheless, some other studies have not observed an increase in asthma risk for specific jobs such as nursing [39-41]. Studies assessing exposures to individual risk factors such as latex, sensitizing agents and disinfectants suggested increased risk. Latex was found to be an occupational risk factor for asthma among health care professionals in numerous studies [9, 42-44]. However, the introduction of latex-free gloves after 2000 in 
many health care institutions reduced the risk of asthma and allergy significantly [43]. Use of disinfectants [43, 45], areosoled medications [43], anaesthetics [46] and several other medications [47] has also been linked to occupational asthma. A number of explanations can be offered on the current results of lack of association between the agents in factor 2 and WRAS. First, underreporting of occupational exposures may contribute to the lack of association. Donnay et al. [48] observed substantial underestimation of self-reported exposure among hospital workers for exposures to cleaning/disinfecting agents. Two estimates of exposures were available in that study: self-report and expert assessment. Underestimation of self-reported exposure was observed for some agents compared to that resulting from expert assessment. Other reports also cited underestimation of exposures to asthma risk factors among health care professionals [49]. Furthermore, reliance on self-reporting for exposures may cause misclassification bias as those with and those without asthma may recall their exposures differently. Another possible explanation for the observed lack of association is that health care professionals (especially those with asthma or asthma symptoms) are more educated and aware of the risk of asthma. They may use precautions to protect against latex and medication allergies such as the use of masks. It is also possible that proper ventilation in hospitals reduces exposure to allergens and asthmagens compared to workplaces for agents in factor 1. Healthy worker effect may also partly explain these results as some workers may change their jobs when they experience recurrent asthma symptoms or exacerbations of asthma.

Current results and results of other cross-sectional studies described above only suggested (and did not confirm) an association between exposure to a specific agent in health care settings and the risk of asthma. The majority of the agents which were linked to occupational asthma or asthma symptoms in health care settings are of low molecular weight type [9]. These agents are irritants but induce other asthma symptoms, such as chest tightness, with a latent period (may be after the shift ends). In addition, the highly complex and varied exposure to volatile substances in the hospital environment complicates establishing a link between a specific agent and the asthma. It was observed that jobs with multiple exposures are common. Zoc et al. (2009) [50] showed that $25 \%$ of the study population of the European Community Respiratory Health Survey had four or more exposures according to assessments using job exposure matrix (JEM). In that same study, there was no association between exposure to low molecular weight agents and asthma. Determination of the culprit exposure agent is challenging unless self-reporting of exposure is compared with other means such as using JEM indices [49]. Even assessing exposures based on broad job categorization using JEM may result in either over- or underestimation of exposures. Individuals in the same job category may experience quite different exposure profiles. For example, exposure frequency and intensity to strong asthmagens such as cleaning and sterilizing products, latex or formaldehyde were different among nurses in the different health departments [51]. Furthermore, Mirabel et al. [52] observed no overall increased risk of asthma among nurses but found an elevated risk among nurses who reported certain occupational exposures such as ammonia or bleach.

Major limitations of the current study is that cross-sectional design did not allow to confirm whether WRAS was caused by persistent and cumulative exposure rather than being sparse response to short-term exposure to allergens. Another limitation is that the use of self-reported exposures may have resulted in recall bias and subsequent exposure misclassification. This study also lacked detailed information on job history, long-term exposure or exposure intensity. However, unlike some of the previous studies which assessed asthma risk in different job titles, we assessed actual exposures to the actual agents that induce or exacerbate asthma. Job titles in some cases do not reflect specific roles and occupational tasks that 
could increase the risk of asthma or WRAS. Another strength is that the current questionnaire assessed the temporality of the respiratory symptoms and their relation to being in or way from work thus allowing to define work-relatedness of asthma symptoms.

\section{CONCLUSIONS}

In conclusion, our results on exposures to factor 1 agents are consistent with the large body of literature reporting increased risk of asthma in certain job exposures such as cleaning agents and metal fumes. Lack of association with exposures to other substances such latex, medications or disinfectants may reflect complexity of exposures in these jobs, or the awareness of risk factors of asthma among HCWs. The current results showing increased risk of exposure to cleaning agents may have public health implications due to widespread use of cleaning agent in homes. Protective measures (e.g. proper ventilation and wearing masks) should be strongly implemented, especially among non-medical staff.

\section{REFERENCES}

[1] Loyo-Berríos, N.I., Irizarry, R., Hennessey, J.G., Tao, X.G. \& Matanoski G., Air pollution sources and childhood asthma attacks in Catano, Puerto Rico. American Journal of Epidemiology, 165(8), pp. 927-935, 2007. DOI: 10.1093/aje/kwk088.

[2] Kemp, J.P., Comprehensive asthma management: guidelines for clinicians. Journal of Asthma, 35, pp. 601-620, 1998. DOI: 10.1172/JCI114338.

[3] Eder, W., Ege, M.J. \& von Mutius E., The asthma epidemic. New England Journal of Medicine, 355(21), pp. 2226-2235, 2006. DOI: 10.1056/NEJMra054308.

[4] van Schayck, O.C., Global strategies for reducing the burden from asthma. Primary Care Respiratory Journal, (2), Vol. 22(no2), pp. 239-243. 2013. DOI: 10.4104/ pcrj.2013.00052.

[5] Balmes, J., Becklake, M, Blanc, P, Henneberger, P, Kreiss, K, Mapp, C, Milton, D, Schwartz, D., Toren, K. \& Viegi, G., Environmental and occupational health assembly, American Thoracic Society. American Thoracic Society statement: Occupational contribution to the burden of airway disease. American Journal of Respiratory and Critical Care Medicine, 167(5), pp. 787-97, 2003.

[6] Buck, R.G., Miles, A.J. \& Ehrlich, R.I., Possible occupational asthma among adults presenting with acute asthma. South African Medical Journal, 90 (9), pp. 884-888, 2000. DOI: org/10.1164/rccm.167.5.787.

[7] Jeebhay, M.F. \& Quirce, S., Occupational asthma in the developing and industrialised world: A review. International Journal of Tuberculosis and Lung Disease, 11(2), pp. 122-133, 2007.

[8] McHugh, M.K., Symanski, E., Pompeii, L.A. \& Delclos, G.L., Prevalence of asthma by industry and occupation in the U.S. working population. American Journal of Industrial Medicine, 53(5), pp. 463-475, 2010. DOI: 10.1002/ajim.20800.

[9] Hayes, J.P. \& Fitzgerald, M.X., Occupational asthma among hospital health care personnel: A cause for concern? Thorax, 49(3), pp. 198-200, 1994. DOI: 10.1136/thx.49.3.198.

[10] White, G.E.1., Mazurek, J.M. \& Moorman, J.E., Asthma in health care workers: 2008 and 2010 Behavioral risk factor surveillance system asthma call-back survey. Journal of Occupational and Environmental Medicine, 55(12):1463-1468, 2013. DOI: 10.1097/ JOM.0000000000000006.

[11] Bang, K., Hnizdo, E. \& Doney, B., Prevalence of asthma by industry in the US population: a study of 2001 NHIS data. American Journal of Industrial Medicine, 47, pp. 500-508, 2005. DOI: 10.1002/ajim.20170. 
[12] Karjalainen, A., Kurppa, K., Martikainen, R. et al., Work is related to a substantial portion of adult-onset asthma incidence in the Finnish population. American Journal of Respiratory and Critical Care Medicine, 164, pp. 565-568, 2001. DOI: 10.1164/ ajrccm.164.4.2012146.

[13] Kogevinas, M., Zock, J-P., Jarvis, D. et al., Exposure to substances in the work-place and new-onset asthma: an international prospective population-based study [ECRHSII]. Lancet, 370, pp. 336-341, 2007. DOI: 10.1016/S0140-6736(07)61164-7.

[14] Liss, G.M., Buyantseva, L., Luce, C.E. et al., Work-related asthma in health care in Ontario. American Journal of Industrial Medicine, 54, pp. 278-284, 2011. DOI: 10.1002/ ajim.20935.

[15] Syabbalo, N., Occupational asthma in a developing country. Chest, 99(2), pp. 528, 1991. DOI: 10.1378/chest.99.2.528-a.

[16] Delclos, G.L., Arif, A.A., Aday, L., Carson, A., Lai, D., Lusk, C., Stock, T., Symanski, E., Whitehead, L.W, Benavides, F.G. \& Antó, J.M., Validation of an asthma questionnaire for use in healthcare workers. Occupational and Environmental Medicine, 63 (3), pp. 173-9, 2006. DOI: 10.1136/oem.2005.021634.

[17] Antonini, J.M., Lewis, A.B., Roberts, J.R. \& Whaley, D.A., Pulmonary effects of welding fumes: review of worker and experimental animal studies. American Journal of Industrial Medicine, 43, pp. 350-360, 2003. DOI: 10.1002/ajim.10194.

[18] Hannu, T., Piipari, R., Kasurinen, H., Keskinen, H., Tuppurainen, M. \& Tuomi, T., Occupational asthma due to manual metal-arc welding of special stainless steels. European Respiratory Journal, 26(4), pp. 736-739, 2005. DOI: 10.1183/09031936.05.00130504.

[19] Keskinen, H., Kalliomäki, P-L. \& Alanko, K., Occupational asthma due to stainless steel welding fumes. Clinical Allergy, 10, pp. 151-159, 1980. DOI: 10.1016/00916749(78)90072-6.

[20] Jaakkola, J.J., Piipari, R. \& Jaakkola, M.S., Occupation and asthma: A population-based incident case-control study. American Journal of Epidemiology 158(10), pp. 981-987, 2003. DOI: 10.1093/aje/kwg238.

[21] Lai, C.Y., Lai, C.H., Chuang, H.C., Pan, C.H., Yen, C.C., Lin, W.Y., Chen, J.K., Lin, L.Y. \& Chuang, K.J., Physicochemistry and cardiovascular toxicity of metal fume PM2.5: A study of human coronary artery endothelial cells and welding workers. Scientific Reports, 19, pp. 335-15, 2016. DOI: 10.2147/IJN.S52239.

[22] Cavallari, J.M. et al., PM2.5 metal exposures and nocturnal heart rate variability: a panel study of boilermaker construction workers. Environmental Health, 7(36), 2008. DOI: $10.1093 /$ jat/29.8.814.

[23] Chan-Yeung, M. \& Malo, J.L., Aetiological agents in occupational asthma. European Respiratory Journal, 7, pp. 346-371, 1994. DOI: 10.1183/09031936.94.07020346.

[24] Huang et al., Association between concentrations of metals in urine and adult asthma: A case-control study in Wuhan, China. PLoS One, 11(5), e0155818, 2016. DOI: 10.1371/ journal.pone.0155818.t006.

[25] Novey, H.S., Habib, M. \& Wells, I.D., Asthma and IgE antibodies induced by chromium and nickel salts. Journal of Allergy and Clinical Immunology, 72 (4), pp. 407-12, 1983. DOI: 10.1016/0091-6749(83)90507-9.

[26] Dumas, O., Donnay, C., Heederik, D.J., Héry, M., Choudat, D., Kauffmann, F. \& Le Moual, N., Occupational exposure to cleaning products and asthma in hospital workers. Occupational and Environmental Medicine, 69(12), pp. 883-889, 2012. DOI: 10.1136/ oemed-2012-100826. 
[27] Piirila, P., Hodgson, U., Estlander, T. et al., Occupational respiratory hypersensitivity in dental personnel. International Archives of Occupational and Environmental Health, 75, pp. 209-216, 2002. DOI: 10.1007/s00420-001-0302-4.

[28] Thickett, K.M., McCoach, J.S., Gerber, J.M. et al., Occupational asthma caused by chloramines in indoor swimming-pool air. European Respiratory Journal, 19, pp. 827832, 2002. DOI: 10.1183/09031936.02.00232802.

[29] Kujala, V.M., Reijula, K.E., Ruotsalainen, E.M. et al., Occupational asthma due to chloramine-T solution. Respiratory Medicine, 89, pp. 693-695, 1995. DOI: 10.1016/09546111(95)90137-X.

[30] Matulonga, B., Rava, M., Siroux, V., Bernard, A., Dumas, O., Pin, I, Zock, J.P., Nadif, R., Leynaert, B. \& Le Moual, N., Women using bleach for home cleaning are at increased risk of non-allergic asthma. Respiratory Medicine, 117, pp. 264-271, 2016. DOI: 10.1016/j.rmed.2016.06.019.

[31] Rosenman, K.D., Reilly, M.J., Schill, D.P. et al., Cleaning products and work-related asthma. Journal of Occupational and Environmental Medicine, 45, pp. 556-563, 2003. DOI: 10.1097/01.jom.0000058347.05741.f9.

[32] Medina-Ramon, M., Zock, J.P., Kogevinas, M. et al., Short-term respiratory effects of cleaning exposures in female domestic cleaners. European Respiratory Journal, 27, pp. 1196-1203, 2006. DOI: 10.1183/09031936.06.00085405.

[33] Shakeri, M S., Dick, F D. \& Ayres, J G., Which agents cause reactive airways dysfunction syndrome (RADS)? A systematic review. Occupational Medicine, 58, pp. 205-211, 2008. DOI: $10.1093 /$ occmed/kqn013.

[34] Arif, A. A. \& Delclos, G. L., Association between cleaning-related chemicals and workrelated asthma and asthma symptoms among healthcare professionals. Occupational and Environmental Medicine, 69 (1), pp. 35-40, 2012. DOI: 10.1136/oem.2011.064865.

[35] Medina-Ramón, M., Zock, J.P., Kogevinas, M., Sunyer, J., Torralba, Y., Borrell, A, Burgos, F. \& Antó, J.M., Asthma, chronic bronchitis, and exposure to irritant agents in occupational domestic cleaning: A nested case-control study. Occupational Environmental Medicine, 62 (9), pp. 598-606, 2005. DOI: 10.1136/oem.2004.017640.

[36] Arif, A.A., Delclos, G.L. \& Serra, C., Occupational exposures and asthma among nursing professionals. Occupational and Environmental Medicine, 66(4), 274-278, 2009. DOI: 10.1136/oem.2008.042382.

[37] Vizcaya, D., Mirabelli, M.C., Gimeno, D., Antó, J.M., Delclos, G.L., Rivera, M., Orriols, R., Arjona, L., Burgos, F. \& Zock, J.P., Cleaning products and short-term respiratory effects among female cleaners with asthma. Occupational and Environmental Medicine, 72(11), pp. 757-63, 2015. DOI: 10.1136/oemed-2013-102046.

[38] Ekpanyaskul, C,. Etiological investigation of unintentional solvent exposure among university hospital staff. Indian Journal of Occupational and Environmental Medicine, 14(3), pp. 100-103, 2010. DOI: 10.4103/0019-5278.75699.

[39] Arif, A.A., Whitehead, L.W., Delclos, G.L., Tortolero, S.R. \& Lee, E.S., Prevalence and risk factors of work related asthma by industry among United States workers: data from the third national health and nutrition examination survey (1988-1994). Occupational and Environmental Medicine, 59(8), pp. 505-11, 2002. DOI: 10.1136/oem.59.8.505.

[40] Kogevinas, M., Antó, J.M., Soriano, J.B. et al., The risk of asthma attributable to occupational exposures. A population-based study in Spain. American Journal of Respiratory and Critical Care Medicine, 154, pp. 137-143, 1996. DOI: 10.1164/ ajrccm.154.1.8680669. 
[41] Karjalainen, A., Kurppa, K., Martikainen, R., Klaukka, T. \& Karjalainen J., Work is related to a substantial portion of adult-onset asthma incidence in the Finnish population. American Journal of Respiratory and Critical Care Medicine, 164, pp. 565-568, 2001. DOI: 10.1164/ajrccm.164.4.2012146.

[42] Marcos, C.1., Lázaro, M., Fraj, J., Quirce, S., de la Hoz, B., Fernández-Rivas, M. \& Losada, E., Occupational asthma due to latex surgical gloves. Annals of Allergy, 7(3), pp. 319-323, 1991. DOI: 10.1111/j.1365-2222.1997.118-az0114.x.

[43] Delclos, G.L., Gimeno, D., Arif, A.A., Burau, K.D., Carson, A., Lusk, C., Stock, T., Symanski, E., Whitehead, L.W., Zock, J.P., Benavides, F.G. \& Antó, J.M., Occupational risk factors and Asthma among Health Care Professionals. American Journal of Respiratory and Critical Care Medicine, 175(7), pp. 667-675, 2007. DOI: 10.1164/ rccm.200609-13310C.

[44] Amr, S. \& Suk, W.A., Latex allergy and occupational asthma in health care workers: adverse outcomes. Environmental Health Perspective, 112(3):378-381, 2004.

[45] Weber, D.J, Consoli, S.A. \& Rutala, W.A., Occupational health risks associated with the use of germicides in health care. American Journal of Infection Control, 44 (5 Suppl), pp. 85-89, 2016. DOI: 10.1016/j.ajic.2015.11.030.

[46] Vellore, A.D.1., Drought, V.J., Sherwood-Jones D, Tunnicliffe B, Moore V.C, Robertson, A.S. \& Burge, P.S., Occupational asthma and allergy to sevoflurane and isoflurane in anaesthetic staff. Allergy, 61(12):1485-6, 2006. DOI: 10.1157/13059846.

[47] Pralong, J.A.1., Cartier, A., Vandenplas O. \& Labrecque M. Occupational Asthma: New Low-Molecular-Weight Causal Agents, 2000-2010. Journal of Allergy (Cairo). 597306, 2012. DOI: 10.1093/occmed/kqp168.

[48] Donnay, C, Denis, M.A., Magis, R., Fevotte, J., Massin, N., Dumas, O., Pin, I., Choudat, D., Kauffmann, F. \& Le Moual, N., Under-estimation of self-reported occupational exposure by questionnaire in hospital workers. Occupational and Environmental Medicine, 68 (8), pp. 611-617, 2011. DOI: 10.1136/oem.2010.061671.

[49] George, L., Delclos, David, Gimeno, Ahmed A., Arif, Fernando G., Benavides, \& JanPaul Zock., Occupational Exposures and Asthma in Health-Care Workers: Comparison of Self-Reports with a Workplace-Specific Job Exposure Matrix. American Journal of Epidemiology, 169 (5), pp. 581-587, 2009. DOI: 10.1093/aje/kwn387.

[50] Zock J.P., Cavallé, N, Kromhout, H., Kennedy, S.M., Sunyer, J., Jaén, A., Muniozguren, N., Payo, F., Almar, E., Sánchez, J.L., Antó, J.M. \& Kogevinas, M. Evaluation of specific occupational asthma risks in a community-based study with special reference to single and multiple exposures. Journal of Exposure Analysis and Environmental Epidemiology, 14(5), pp. 397-403, 2004. DOI: 10.1038/sj.jea.7500337.

[51] Liss, G.M., Buyantseva, L., Luce, C.E. et al., Work-related asthma in health care in Ontario. American Journal of Industrial Medicine, 54, pp. 278-284, 2011. DOI: 10.1002/ ajim.20935.

[52] Mirabelli, M.C.1., Zock, J.P., Plana, E., Antó, J.M., Benke, G., Blanc, P.D., Dahlman-Höglund, A., Jarvis, D.L., Kromhout, H., Lillienberg, L., Norbäck, D., Olivieri, M., Radon, K., Sunyer, J., Torén, K., van Sprundel, M., Villani, S. \& Kogevinas, M., Occupational risk factors for asthma among nurses and related healthcare professionals in an international study. Occupational and Environmental Medicine, 64, pp. 474-479, 2007. DOI: 10.1136/oem.2006.031203. 